\title{
Comparison of accuracy of forecasting methods of convective precipitation
}

\author{
David Šaur ${ }^{1, *}$, Lukáš Pavlík ${ }^{2}$ \\ ${ }^{1}$ Tomas Bata University in Zlin, Faculty of Applied Informatics, Nad Stráněmi 4511, Zlin, Czech Republic \\ ${ }^{2}$ Tomas Bata University in Zlin, Faculty of Applied Informatics, Nad Stráněmi 4511, Zlin, Czech Republic
}

\begin{abstract}
This article is focused on the comparison of the accuracy of quantitative, numerical, statistical and nowcasting forecasting methods of convective precipitation including three flood events that occurred in the Zlin region in the years 2015 - 2017. Quantitative prediction is applied to the Algorithm of Storm Prediction for outputs "The probability of convective precipitation and The statistical forecast of convective precipitation ". The quantitative prediction of the probability of convective precipitation is primarily compared with the precipitation forecasts calculated by publicly available NWP models; secondary to statistical and nowcasting predictions. The statistical prediction is computed on the historical selection criteria and is intended as a complementary prediction to the first algorithm output. The nowcasting prediction operates with radar precipitation measurements, specifically with X-band meteorological radar outputs of the Zlín Region.Compared forecasting methods are used for the purposes of verification and configuration prediction parameters for accuracy increase of algorithm outputs.
\end{abstract}

\section{Introduction}

The prediction of convective precipitation and dangerous phenomena is the current problem of meteorology and hydrology regarding its social impact. The formation of these extreme weather phenomena is closely related to the formation of convective precipitation with an area of several square kilometers, and occasionally to hundreds $\mathrm{km}^{2}$, the duration of several minutes or hours. Moreover, this characteristic of convective precipitation is a fundamental problem of current forecasting systems [1, $3]$.

The prediction of convective precipitation is realized by numerical weather prediction (NWP) models and nowcasting methods using meteorological radars or a distance measurement of rainfall and clouds, such as meteorological satellites and aerological radiosondes, where we can obtain a forecast lead time with a maximum of two hours $[4,5,6]$. At present, nowcasting methods have been complemented by statistical and probabilistic prediction of situation. This approach integrated with principles of nowcasting has been studied in many studies $[7,8,9]$. The second approach is based on a quantitative evaluation of conditions of convective precipitation clouds using NWP models and statistics historical situations. The quantitative assessment focuses on the estimation of future weather developments for a longer forecast lead time, ranging from 6 to 24 hours $[10,11,12]$. This approach has also been developed in the Algorithm of Storm Prediction, which implements the prediction of convective precipitation and dangerous phenomena. The primary aim of this article is to compare the accuracy of predictive convective precipitation methods to 63 storm situations and three flood events in the years 2015 2017. Verified plans are part of the statistical and quantitative prediction of convective precipitation using the Algorithm of Storm Prediction and the very short casting forecasts by Nowcast TITAN X-band of the meteorological radar of the Zlín Region. At the same time, the outputs of these methods are compared with the measured data from ground meteorological stations in the Zlín Region. The purpose is to provide information on the accuracy of the different ways used for verification of the predicted situations and to forecast the intense convective precipitation.

\section{Methods}

The evaluation of the accuracy of forecasting convective precipitation is realized by these forecasting tools and methods:

1. Algorithm of Storm Prediction (statistical and quantitative forecast of convective precipitation).

2. X-band meteorological radar of the Zlín Region (Nowcast TITAN product).

The predictions were verified by data from a network of stations of the Czech Hydrometeorological Institute.

\subsection{Algorithm of Storm Prediction}

The Algorithm of Storm Prediction is an application developed to forecast convective precipitation and dangerous accompanying phenomena that may cause

Corresponding author: saur@utb.cz 
floods. This algorithm calculates seven outputs for each 3-hour interval particularly regarding predictions:

- precipitation occurrence for territory of the municipality of extended powers (MPE) and its regions,

- time occurrence of convective precipitation and

- forecast lead time of 6 - 24 hours $[1,2]$.

This algorithm generates a report of outputs which is computed on ten phases shown in Table 1:

Table 1. Forecast's phases and outputs of the algorithm [1]

\begin{tabular}{|c|c|}
\hline Forecast phases & Forecast outputs \\
\hline $\begin{array}{l}\text { 1. Time } \\
\text { intervals }\end{array}$ & $\begin{array}{c}\text { Time occurrence of } \\
\text { precipitation, } \\
\text { Occurrence of } \\
\text { precipitation }\end{array}$ \\
\hline $\begin{array}{c}\text { 2. General } \\
\text { characteristic }\end{array}$ & $\begin{array}{c}\text { A general characteristic of } \\
\text { the predicted situation }\end{array}$ \\
\hline $\begin{array}{l}\text { 3. Air mass of } \\
\text { conditions }\end{array}$ & $\begin{array}{l}\text { Atmosphere instability, } \\
\text { Trigger a Support } \\
\text { mechanism of convection, } \\
\text { Deep Layer Shear } 0-6 \mathrm{~km} \text {, } \\
\text { Dangerous phenomena, } \\
\text { Organization and } \\
\text { Propagation of storms }\end{array}$ \\
\hline $\begin{array}{l}\text { 4. Local } \\
\text { conditions }\end{array}$ & $\begin{array}{l}\text { Temperature, Moisture, } \\
\text { Wind and Orographic } \\
\text { conditions in the ground } \\
\text { level of atmosphere }\end{array}$ \\
\hline $\begin{array}{l}\text { 5. Storm } \\
\text { intensity }\end{array}$ & Storm intensity (3. phase) \\
\hline $\begin{array}{l}\text { 6. Dangerous } \\
\text { phenomena }\end{array}$ & $\begin{array}{l}\text { Torrential rainfall, Hail, } \\
\text { Strong wind gusts, } \\
\text { Tornadoes }\end{array}$ \\
\hline $\begin{array}{l}\text { 7. Phases } \\
\text { summary }\end{array}$ & $\begin{array}{l}\text { The probability of } \\
\text { occurrence and rainfall } \\
\text { intensity, Risk of } \\
\text { dangerous phenomena, } \\
\text { Risk of flash floods }\end{array}$ \\
\hline $\begin{array}{l}\text { 8. Statistical } \\
\text { for ecast }\end{array}$ & $\begin{array}{c}\text { Historical situation }+ \\
\text { Storm tracks }\end{array}$ \\
\hline $\begin{array}{l}\text { 9. Forecast } \\
\text { report }\end{array}$ & $\begin{array}{c}\text { Summarization a } \\
\text { visualization of algorithm } \\
\text { outputs }\end{array}$ \\
\hline
\end{tabular}

Outputs of the algorithm called "the probability of precipitation occurrence (7th phase) and the statistical forecast (8th phase)" are evaluation subject of their accuracy compared to nowcasting output. These outputs are calculated on data from publicly available NWP models $[1,2]$.

Table 2. Outputs classification [1]

\begin{tabular}{|c|c|c|c|}
\hline Coefficients & $\begin{array}{c}\text { Probability } \\
\text { of } \\
\text { precipitation }\end{array}$ & $\begin{array}{c}\text { Radar } \\
\text { reflectivity } \\
(\mathrm{dBZ}) / \text { rainfall }\end{array}$ & $\begin{array}{c}\text { Colour } \\
\text { of } \\
\text { radar }\end{array}$ \\
\hline
\end{tabular}

\begin{tabular}{|c|c|c|c|}
\hline & $\begin{array}{c}\text { occurrence } \\
\text { and statistics }\end{array}$ & $\begin{array}{c}\text { intensity } \\
(\mathbf{m m} / \mathbf{h r})\end{array}$ & $\begin{array}{c}\text { reflecti- } \\
\text { vity }\end{array}$ \\
\hline 0 & $0-0,24$ & $<52(<48)$ & \\
\hline 1 & $0,25-0,49$ & $52(65)$ & \\
\hline 2 & $0,50-0,74$ & $56(115)$ & \\
\hline 3 & $0,75-1$ & $=>60(200)$ & \\
\hline
\end{tabular}

Classification of forecasting outputs, including outputs from the meteorological radar Zlín Region (product Nowcast TITAN) is listed in Table 2.

Verification outputs are performed by the Accuracy verification criterion, calculated as the ratio of all favorable situations to the total number of all cases [1].

\subsubsection{Forecast of occurrence and intensity rainfall}

This output is one of the leading prediction algorithm outputs that are calculated by the following formula:

$$
P_{\text {prec }}(A)=P(S I)+P(L C)
$$

where $\mathrm{P}$ (SI) is the probability of storm intensity (comparable to CHMI alerts) and P (LC) is the probability of local conditions influencing the initiation of atmospheric convection, which are thermal, humidity, wind and orographic conditions $[1,2]$.

\subsubsection{Statistical forecast of convective precipitation}

The statistical forecast is a part of the 8th stage of the algorithm, which contains two partial outputs with the prediction of the occurrence and intensity convective precipitation for:

- historical convective rainfall situation and

- storm tracks.

The historic selection of the predicted situation is based on criteria such as the direction of rainfall, temperature, humidity, wind direction and velocity at $1000-300 \mathrm{hPa}$ and local conditions. The aim is to determine the correlation dependence between criteria using the Pearson correlation coefficient:

$$
\left.\rho_{X, Y}=\frac{E(X Y)-E(X) E(Y)}{\sqrt{E\left(X^{2}\right)-E^{2}(X)} \sqrt{E\left(Y^{2}\right)-E^{2}(Y)}}\right),
$$

where random variables $X=E(X 2)$ and $Y=E$ (Y2) represent the criteria of the historical and predicted situation. The correlation coefficient takes values from 1 to 1 , with the positive correlation dependence, is defined for a range of 0.5 to 1 for the eighth phase algorithm output. The output is the probability of occurrence and intensity convective precipitation as well as the first evaluated output $[1,2]$.

The storm track is determined by the prediction of the probability of the precipitation occurrence for which the statistic is associated with frequency precipitation according to the direction of rainfall movement $[1,2]$. 


\subsection{Meteorological radar of the Zlín Region}

The very short forecast (nowcasting) was evaluated on outputs from the Nowcast TITAN, which is one of the products of the meteorological radar of the Zlín Region. This meteorological radar is part of the Information, Notification and Warning System of the Zlín Region, which provides an effective method of communication between municipalities with extended powers for crisis management, including warning of the population [13].

The primary physical variable is the radar reflectivity that is calculated by the Marshall-Palmer relation [13, 14]:

$$
Z=a I^{b}
$$

where $a$ a $b$ are experimentally constants ( $\mathrm{a}=200, \mathrm{~b}=1,6)$. In practice, the radar reflectivity $Z$ is recalculated to the rainfall intensity $I$ according to the formula $[13,14]$ :

$$
I=10(Z-10 \log (a)) / 10 b
$$

The Nowcast TITAN radar product provides information on the future distribution of the rainfall field with 60 minutes of the forecast lead time. Firstly, this product output is computed by selecting precipitation fields with the defined threshold of radar reflectivity. In the final phase, the predicted area of the precipitation occurrence is calculated by the length of arrows representing the measured moving speed of rainfall [13].

\section{Results}

The accuracy of predictive methods is compared with 63 situations and flash flood events that occurred in the Zlin Region in the years of 2015 - 2017:

- July 24, 2015,

- August 5, 2016,

- July 22, 2017.

\subsection{A case study on July 24,2015}

Very intense convective precipitation hit the eastern part of the Czech Republic on July 24, 2015, accompanied by hail, strong wind gusts, and local torrential rainfall, which is occurred on the cold front in the afternoon and evening hours [1].

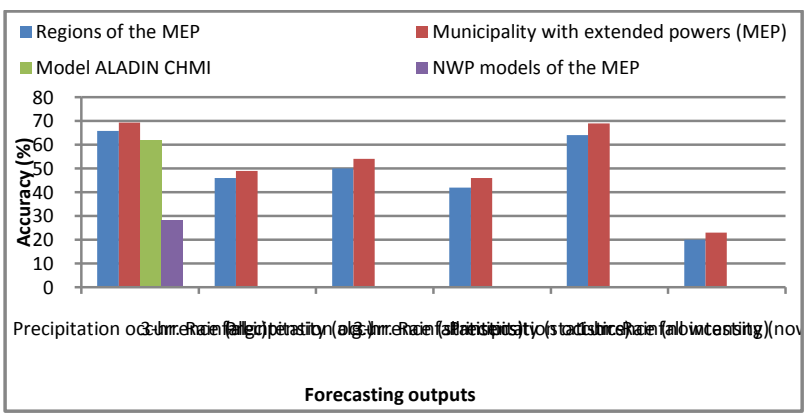

Graph 1. The accuracy of prediction method on July 24, 2015 [1]
Graph 1 state that the quantitative prediction achieved the highest accuracy. At the same time, the nowcasting forecast produced comparable results. However, the accuracy of the nowcasting rainfall intensity forecast was very low due to the considerable variation in the precipitation intensity over time. The statistical prediction had the most reasonable skill due to the small number of historical situations.

\begin{tabular}{|c|c|c|c|c|}
\hline $\begin{array}{l}24.7 .2015 \\
(18-21: 00)\end{array}$ & $\begin{array}{l}\text { Predi- } \\
\text { ction }\end{array}$ & $\begin{array}{c}\text { Predi- } \\
\text { ction }\end{array}$ & $\begin{array}{c}\text { Predi- } \\
\text { ction }\end{array}$ & Real state \\
\hline $\begin{array}{l}\text { MEP of the } \\
\text { Zlín region, } \\
\text { reported } \\
\text { flash flood } \\
\text { event }\end{array}$ & $\begin{array}{c}\text { Rainfall } \\
\text { intensity } \\
(\mathrm{mm} / \\
3 \mathrm{hr} .)- \\
\text { Algo- } \\
\text { rithm }\end{array}$ & $\begin{array}{c}\text { Rainfall } \\
\text { intensity } \\
\text { (mm/3hr.) } \\
\text { - statistical } \\
\text { prediction - } \\
11.7 . \\
2011)\end{array}$ & $\begin{array}{c}\text { Radar } \\
\text { refle- } \\
\text { Rain- } \\
\text { fall } \\
\text { intensi- } \\
\text { ty } \\
(\mathrm{dBZ} / \\
\mathrm{mm} / \mathrm{hr} . \\
)\end{array}$ & $\begin{array}{l}\text { Rainfall } \\
\text { in mm } \\
\text { (station) }\end{array}$ \\
\hline $\begin{array}{l}\text { Uherské } \\
\text { Hradiště }\end{array}$ & 0 & $3-9$ & $\begin{array}{c}56 \\
(115)\end{array}$ & $\begin{array}{c}7 \text { - Staré } \\
\text { Hutě }\end{array}$ \\
\hline Otrokovice & $3-9$ & $3-9$ & 0 & 0 \\
\hline Kroměříž & $3-9$ & $3-9$ & $\begin{array}{c}56 \\
(115)\end{array}$ & $\begin{array}{c}6- \\
\text { Kroměřížz }\end{array}$ \\
\hline Holešov & $3-9$ & $3-9$ & $\begin{array}{c}56 \\
(115)\end{array}$ & 6 - Holešov \\
\hline Zlín & $10-29$ & $10-29$ & $\begin{array}{c}60 \\
(200) \\
\end{array}$ & $23-$ Zlín \\
\hline Bystřice & $3-9$ & $10-29$ & $\begin{array}{c}56 \\
(115)\end{array}$ & 4 - Bystřice \\
\hline $\begin{array}{l}\text { Valašské } \\
\text { Meziříčí }\end{array}$ & 0 & $10-29$ & $48(37)$ & 0 \\
\hline Rožnov & $3-9$ & $3-9$ & $52(65)$ & 0 \\
\hline Vsetín & $3-9$ & $10-29$ & $\begin{array}{c}60 \\
(200) \\
\end{array}$ & $\begin{array}{c}12 \text { - } \\
\text { Maruška }\end{array}$ \\
\hline Vizovice & $3-9$ & $3-9$ & $48(37)$ & 4 Vizovice \\
\hline $\begin{array}{l}\text { Valašské } \\
\text { Klobouky }\end{array}$ & $3-9$ & 0 & 0 & 0 \\
\hline Luhačovice & $3-9$ & $3-9$ & 48 (37) & 0 \\
\hline $\begin{array}{c}\text { Uherský } \\
\text { Brod }\end{array}$ & 0 & 0 & $48(37)$ & 0 \\
\hline
\end{tabular}

Table 3. Verification of flash flood event on July 24, 2015 [1]

As can be seen in Table 3, the quantitative, numerical, statistical and nowcasting forecast of convective precipitation corresponded to the measured rainfall in the central part of the Zlín Region (Zlín station $-23 \mathrm{~mm} / 3$ hours) [1].

\subsection{A case study on August 5, 2016}

The local flash flood originated a combination of the repeated occurrence of intense convective precipitation and the extreme soil saturation in the south-eastern part of the Zlín Region in the town Valašské Klobouky. This intense rainfall occurred on a cold front, which slowly moved from south to north. The torrential rainfall caused 
local flooding on the Brumovka, including damage to municipal property and infrastructure within $60 \mathrm{~min}$. [1].

As revealed by Table 4, the convective rainfall occurred across the whole territory of the Zlín Region. This flat occurrence of convective precipitation was also confirmed by all predictive methods, except for nowcasting meteorological radar outputs of the Zlín Region, which did not predict rainfall in the western and northern parts of the Zlín Region. Convective precipitation with intensity above $20 \mathrm{~mm}$ was measured at the station Brumov Bylnice, including a consistent prediction of all methods.

Table 4. Verification of flash flood event on August 5, 2016 [1]

\begin{tabular}{|c|c|c|c|c|}
\hline $\begin{array}{l}5.8 .2016 \\
(21-24: 00)\end{array}$ & $\begin{array}{l}\text { Predi- } \\
\text { ction }\end{array}$ & $\begin{array}{c}\text { Predi- } \\
\text { ction }\end{array}$ & $\begin{array}{c}\text { Predi- } \\
\text { ction }\end{array}$ & $\begin{array}{l}\text { Real } \\
\text { state }\end{array}$ \\
\hline $\begin{array}{l}\text { MEP of the } \\
\text { Zlín region, } \\
\text { reported } \\
\text { flash flood } \\
\text { event }\end{array}$ & $\begin{array}{c}\text { Rainfall } \\
\text { intensity } \\
(\mathrm{mm} / \\
3 \mathrm{hr} .)- \\
\begin{array}{c}\text { Algo- } \\
\text { rithm }\end{array}\end{array}$ & $\begin{array}{c}\text { Rainfall } \\
\text { intensity } \\
\text { (mm/ } 3 \mathrm{hr} \text {.) } \\
\text { - statistical } \\
\text { prediction - } \\
\quad 27.7 . \\
2011)\end{array}$ & $\begin{array}{c}\text { Radar } \\
\text { refle- } \\
\text { Rain- } \\
\text { fall } \\
\text { intensi- } \\
\text { ty } \\
(\mathrm{dBZ} / \\
\mathrm{mm} / \mathrm{hr} \text {. } \\
)\end{array}$ & $\begin{array}{l}\text { Rainfall } \\
\text { in mm } \\
\text { (station) }\end{array}$ \\
\hline Uh.Hradišstě & $10-29$ & $10-29$ & $48(37)$ & $\begin{array}{c}11 \text { - Staré } \\
\text { Hutě }\end{array}$ \\
\hline Otrokovice & $3-9$ & $10-29$ & 0 & $\begin{array}{c}8- \\
\text { Košíky }\end{array}$ \\
\hline Kroměříž & $3-9$ & $3-9$ & 0 & $\begin{array}{c}8- \\
\text { Kroměříž } \\
\end{array}$ \\
\hline Holešov & $3-9$ & $\operatorname{nad} 30$ & 0 & $\begin{array}{c}9- \\
\text { Holešov }\end{array}$ \\
\hline Zlín & $3-9$ & $10-29$ & $48(37)$ & $\begin{array}{c}6 \text { - Zlín- } \\
\text { Štípa }\end{array}$ \\
\hline Bystřice & $10-29$ & $10-29$ & $52(65)$ & $\begin{array}{c}9- \\
\text { Bystřice }\end{array}$ \\
\hline $\begin{array}{l}\text { Valašské } \\
\text { Meziříčí }\end{array}$ & $3-9$ & $3-9$ & 0 & $\begin{array}{c}7 \text { - } \\
\text { Valašské } \\
\text { Meziříčí }\end{array}$ \\
\hline Rožnov & $3-9$ & nad 30 & 0 & $\begin{array}{c}15 \text { - } \\
\text { Horní } \\
\text { Bečva }\end{array}$ \\
\hline Vsetín & $10-29$ & $10-29$ & $52(65)$ & $\begin{array}{c}24 \text { - Val. } \\
\text { Senice }\end{array}$ \\
\hline Vizovice & $0-3$ & $3-9$ & $52(65)$ & $\begin{array}{c}9 \text { - } \\
\text { Vizovice }\end{array}$ \\
\hline $\begin{array}{l}\text { Valašské } \\
\text { Klobouky }\end{array}$ & $10-29$ & nad 30 & $52(65)$ & $\begin{array}{c}21- \\
\text { Brumov- } \\
\text { Bylnice }\end{array}$ \\
\hline Luhačovice & $10-29$ & $3-9$ & $48(37)$ & $\begin{array}{l}14- \\
\text { Luha- } \\
\text { čovice }\end{array}$ \\
\hline Uh. Brod & $10-29$ & $\operatorname{nad} 30$ & $48(37)$ & $\begin{array}{c}14 \text { - } \\
\text { Strání }\end{array}$ \\
\hline
\end{tabular}

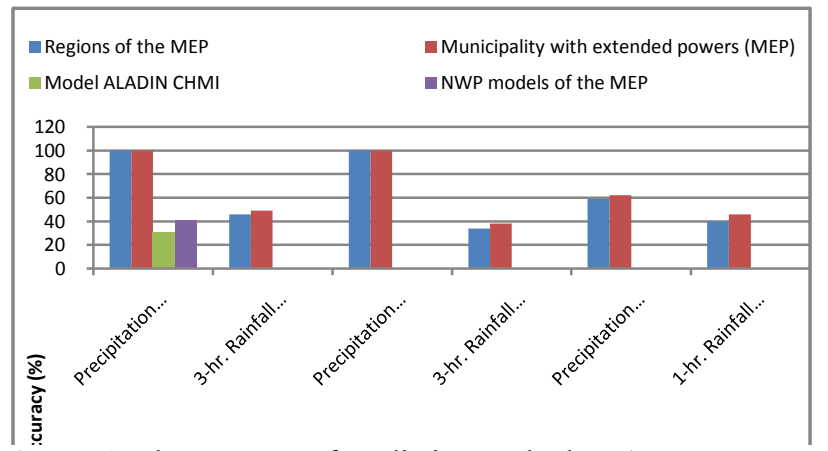

Graph 2. The accuracy of prediction method on August 5, 2016 [1].

Graph 2 demonstrate the very high success rate of the predicted convective precipitation for this event regarding quantitative and statistical prediction against NWP models. On the contrary, the nowcasting prediction was significantly lower due to the flat occurrence of rainfall from which it was not possible to determine precisely the future presence of convective precipitation.

\subsection{A case study on July 22, 2017}

This case study is characterized by a very local precipitation with the intensity above $30 \mathrm{~mm} / \mathrm{hr}$, which occurred in the area of several square kilometres in the northern regions of Luhačovice. Local flash floods did not cause significant damage to the property of the population, because it occurred outside urbanized areas. Flood damage reached the order of several million crowns, especially in the case of damage to transport infrastructure and nearby meadows and fields. The formation of intense rainfall was significantly supported by the occluded front which remained in place for several hours [1].

Table 5. Verification of flash flood event on July 22, 2017 [1]

\begin{tabular}{|c|c|c|c|c|}
\hline $\begin{array}{c}22.7 .2017 \\
(15-18: 00)\end{array}$ & $\begin{array}{l}\text { Predi- } \\
\text { ction }\end{array}$ & $\begin{array}{l}\text { Predi- } \\
\text { ction }\end{array}$ & $\begin{array}{l}\text { Predi- } \\
\text { ction }\end{array}$ & $\begin{array}{l}\text { Real } \\
\text { state }\end{array}$ \\
\hline $\begin{array}{l}\text { MEP of the } \\
\text { Zlin region, } \\
\text { reported } \\
\text { flash flood } \\
\text { event }\end{array}$ & $\begin{array}{c}\text { Rainfall } \\
\text { intensity } \\
(\mathrm{mm} / \\
\text { 3hr.) - } \\
\text { Algo- } \\
\text { rithm }\end{array}$ & $\begin{array}{c}\text { Rainfall } \\
\text { intensity } \\
\text { (mm/3hr.) } \\
\text { - statistical } \\
\text { prediction( } \\
27.7 . \\
2016)\end{array}$ & $\begin{array}{c}\text { Radar } \\
\text { refle- } \\
\text { Rain-fall } \\
\text { intensi-ty } \\
(\mathrm{dBZ} / \\
\mathrm{mm} / \mathrm{hr} .)\end{array}$ & $\begin{array}{c}\text { Rainfal } \\
1 \text { in mm } \\
\text { (station } \\
\text { ) }\end{array}$ \\
\hline Uh.Hradiště & 0 & $3-9$ & $56(115)$ & $\begin{array}{c}3- \\
\text { Hluk }\end{array}$ \\
\hline Otrokovice & 0 & 0 & 0 & 0 \\
\hline Kroměříž & 0 & $3-9$ & 0 & 0 \\
\hline Holešov & 0 & $3-9$ & 0 & 0 \\
\hline Zlín & $10-29$ & $3-9$ & $60(200)$ & 0 \\
\hline Bystřice & 0 & $3-9$ & 0 & 0 \\
\hline
\end{tabular}




\begin{tabular}{|c|c|c|c|c|}
\hline $\begin{array}{c}\text { Valašské } \\
\text { Meziříčí }\end{array}$ & 0 & $3-9$ & 0 & 0 \\
\hline Rožnov & 0 & $10-29$ & 0 & 0 \\
\hline Vsetín & $3-9$ & $10-29$ & 0 & $\begin{array}{c}3-\text { Val. } \\
\text { Polank } \\
\text { a }\end{array}$ \\
\hline Vizovice & $3-9$ & $3-9$ & $48(37)$ & 0 \\
\hline $\begin{array}{c}\text { Valašské } \\
\text { Klobouky }\end{array}$ & $3-9$ & $3-9$ & $48(37)$ & 0 \\
\hline $\begin{array}{c}\text { Luhačovice } \\
\text { Uh. Brod }\end{array}$ & $30-49$ & $3-9$ & $60(200)$ & $\begin{array}{c}36- \\
\text { Horní } \\
\text { Lhota }\end{array}$ \\
\hline 0 & $3-9$ & $48(37)$ & 0 \\
\hline
\end{tabular}

As described in Table 5, only the quantitative and nowcasting forecast of precipitation corresponded with the measured rainfall at Horní Lhota station $(36 \mathrm{~mm} /$ hour). On the contrary, the statistical forecast reported the results for the entire territory of the Zlín Region and at the same time did not emphasize the future occurrence of intense precipitation in the MEP Luhačovice and Zlín. This fact was mainly due to the limited selection of the low number of historical situations as well as the first case study.

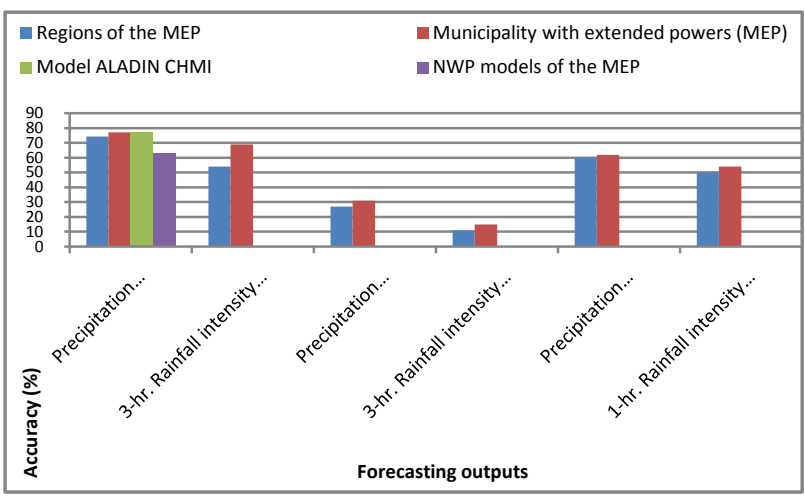

Graph 3. The accuracy of prediction method on July 22, 2017 [1]

Graph 3 illustrate that quantitative, numerical and nowcasting methods achieved the highest accuracy of convective precipitation predictions, in particular, the Algorithm of Storm Prediction with the more accurate forecast of intense precipitation for the MEP Luhačovice. The lowest accuracy was reported in the statistical forecasts of rainfall intensity where based on the selection of historical situations and situation similar to this flood event was not found.

\subsection{The accuracy of prediction methods in years of $2015-2017$}

This chapter aims to present the results of the evaluation of the accuracy of the quantitative, numerical, statistical and nowcasting predictions of convective precipitation for 63 situations that were verified for the territory of the Zlín Region in the years 2015-2017.

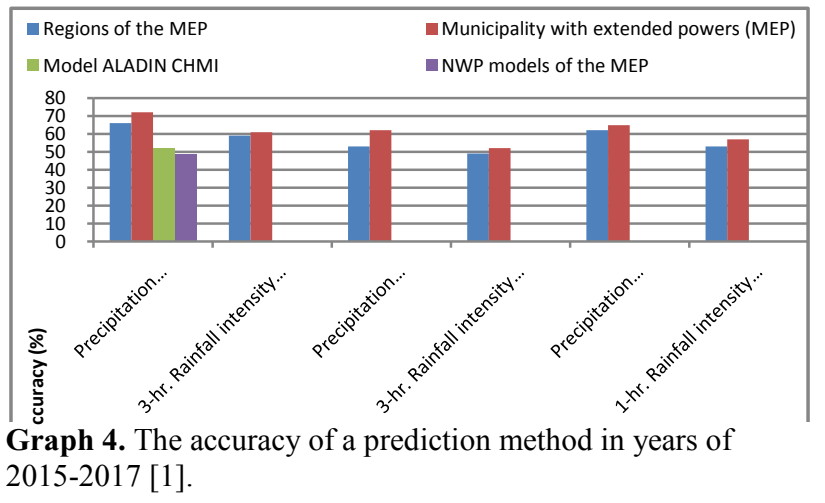

Graph 4 show that the highest accuracy of convective precipitation prediction was achieved with the quantitative prediction used in the Algorithm of Storm Prediction. Forecast computed from NWP models reached $20 \%$ lower than the quantitative prediction. The main reasons for this difference in the accuracy of both predictive methods were certain limitations of NWP models such as insufficient input data from ground meteorological stations, low horizontal resolution of models, and the use of a hydrostatic core model which is not primarily developed for atmospheric convection modeling. Nowcasting forecast had the second highest accuracy using radar precipitation measurements. The main limitation is the deficient forecast lead time - only for 60 minutes, which is insufficient for the realization of preventive flood protection measures of the Fire Rescue Service. On the other hand, the nowcasting prediction can be more accurate especially for very flat convective precipitation, which may affect areas of several tens to hundreds of square kilometers. The statistical forecast was the lowest accuracy due to the small number of historical situations.

\section{Conclusions}

This article aimed to provide information on methods designed to predict intense convective precipitation that may cause flash floods. The accuracy of quantitative, numerical, statistical and nowcasting predictions is verified in three flash floods, including 63 events, which were recorded by stationary measurements in the Zlin Region between years of 2015 and 2017.

The quantitative prediction of convective precipitation used to compute all outputs in the Algorithm of Storm Prediction, which achieved the highest accuracy of the predicted occurrence and intensity rainfall for all situations, including flood events in the years of 2015-2017. This method is applicable in combination with nowcasting for the prediction of convective precipitation with the accuracy of $60-70 \%$ for territory of municipalities with extended powers. Nowcasting prediction can provide more accurate information on the occurrence of convective rainfall; however, with a short forecasting lead time. The statistical prediction is usable for an orientation view of a given situation that is intended to be compared to other predictive methods or as a backup output in the case of 
restricting access to publicly available data from NWP models on the Internet.

The limitation of this study regarding the comparison of the evaluation results of the accuracy of the individual predictive methods is the low number of verified events. Future research will focus on ascertaining the quantitative prediction of tens to hundreds of events for the whole territory of the Czech Republic, including a comparison with these predictive methods. The primary goal will be to increase the accuracy of Algorithm of Storm Prediction by verification to offer the inclusion in the Czech Hydrometeorological Institute operating mode.

This work was supported by the project No. CEBIA-Tech LO1303, A2.4 - ICT for support of crisis management.

\section{References}

1. D. Šaur, Information support for crisis management of the region in terms of assessment of flood events, 172 (2017)

2. D. Šaur, Algorithm of Storm Prediction: Technical specification (2018)

3. L. Březková, M. Šálek, P. Novák, H. Kyznarová, M. Jonov, IFIP Advances in Information and Communication Technology, 359, 8 (2011)

4. S. Das, R. Chakraborty, A. Maitra, Advances in Space Research, 60, 12 (2017)

5. V. Bližňák, Z. Sokol, P. Zacharov, J. Atmospheric Research., 184, 11 (2017)

6. A. Atencia, I. Zawadski, J. Monthly Weather Review, 143, 19 (2015)

7. R. Osinski, F. Bouttier, J, Meteorological Applications, 25, 14 (2018)

8. B.L. Medina, L. A. T. Machado, J. Natural Hazards, 89, 17 (2017)

9. Z. Sokol, J. Mejsnar, L. Pop, V. Bližňák, J. Atmospheric Research, 194, 13 (2017)

10. S. Gao, D. Huang, J. Atmosphere, 8, 12 (2017)

11. L. Huang, Y. Luo. J. of Geophysical Research: Atmospheres, 122, 23 (2017)

12. O. Nuissier, C. Marsigli, B. Vincendon, A. Hally, F. Bouttier, A. Montani, T. Paccagnella, Quarterly Journal of the Royal Meteorological Society, 142, 15 (2016)

13. D. Šaur, P. Tomášek. Matec Web of Conferences (2016)

14. D. Řezáčová, et al., Physics of clouds and precipitation. 2, 574 (2007) 